\title{
Interfaces
}

\section{Finding Purpose in the Photographs of Others: Ransom Riggs and Isabelle Monnin}

\section{Michèle Bacholle}

\section{(2) OpenEdition \\ 1 Journals}

Electronic version

URL: http://journals.openedition.org/interfaces/648

DOI: 10.4000/interfaces.648

ISSN: 2647-6754

Publisher:

Université de Bourgogne, Université de Paris, College of the Holy Cross

Printed version

Date of publication: 21 June 2019

Number of pages: 85-99

ISSN: 1164-6225

\section{Electronic reference}

Michèle Bacholle, "Finding Purpose in the Photographs of Others: Ransom Riggs and Isabelle Monnin", Interfaces [Online], 41 | 2019, Online since 21 June 2019, connection on 07 January 2021. URL: http:// journals.openedition.org/interfaces/648; DOI: https://doi.org/10.4000/interfaces.648

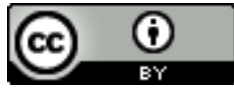

Les contenus de la revue Interfaces sont mis à disposition selon les termes de la Licence Creative Commons Attribution 4.0 International. 


\title{
FINDING PURPOSE IN THE PHOTOGRAPHS OF OTHERS: RANSOM RIGGS AND ISABELLE MONNIN
}

\author{
Michèle Bacholle \\ Eastern Connecticut State University
}

Although photographs have been included in French fiction since the $1890 \mathrm{~s},{ }^{1}$ it is only in the past thirty years or so that the interaction of text and images has spurred an explosion of critical studies. This observation is particularly true when it comes to French literature-Marie-Dominique Garnier's edited book Jardins d'hiver: Littérature et photographie came out in 1997. Such studies have soared in the 2000s, attesting to the fact that a new genre was born, albeit one hard to name: photo-novels and photo-narratives (Daniel Grojnowski), photoliterature (François Soulages), phototexts (Ari Blatt), photofiction and photobiography (Gilles Mora), ph-auto•bio graphy (Michèle Bacholle) or yet photo-textuality, as I referred to my own photo-textual project on the Algerian war of independence. Soulages, who calls such projects co-creations, identifies three kinds of such unions: the first is created by someone who is neither the photographer nor the writer, the second by two co-creators, but one is more involved than the other, ${ }^{2}$ the third is when both artists decide to create together (240-1). Even though their co-creator is unknown to them, Ransom Riggs' and Isabelle Monnin's works fall into the second category and support Grojnowski's observation that when inserted in a text, a photograph can change from personal to documentary or artistic, it can become fiction ("se fictionnalise," 125). Both Riggs and Monnin, although differently, have fictionalized existing photographs, have repurposed photographs of and by others. In both their works, neither medium overshadows the other. If both writers abide by Roland Barthes's famous "that-has-been" ("ça-a-été," Chambre 13), they depart from that frozen moment in time and by their writing, give movement to the still, mute representations of life. They may abide more by Soulages's "that-has-been-played" ("ça-a-été-joué," 65), finding inspiration in the inherent "theatrality" of photographs. Both used pictures that they did not take, that they did not even own at first, and provided them with a context and a meaning, since the original one(s) is/are lost - thus disproving Timothy Dow Adams' remark that "any photograph that purports to represent a fictional character must itself necessarily be fictional" (2). For both, pictures provided an atmosphere and a décor, but at the same time bore a certain indeterminacy, a "béance," or rift (Buignet 501), from

Georges Rodenbach's Bruges-la-Morte (I892) was the first novel in French to feature photographs.

The photographer takes pictures based on the text or the writer writes a text based on the pictures. 
which their fiction could emerge. Not only has Riggs' and Monnin's writing made the photographs no longer "indifferent," 3 with them we are no longer in Barthes's binary "denoted" vs "connoted message" (the photograph itself vs the writing), but in the invented message. I will first examine the specific use Riggs and Monnin make of their photographs of others, which enter in collusion - and not "collision" (Oberhuber 3) - with the texts they wrote from them. Both works allude to photographs' polysemous nature (Soulages 236-7). Whereas Riggs was merely fascinated by the eeriness of old snapshots and contented with building a fantasy world from them, we will see that Monnin's photo-textual project is far more complex, as it forces us to reconsider the boundaries between the personal and the collective and lends itself to a psychological approach. Their project will also make us mull over the role of the reader who, because they are also a viewer, can no longer read in the same way (Oberhuber 5) and must partake in the creation of meaning.

\section{Ransom Riggs: Spurring the reader-viewer into action}

In a "Conversation" featured in the paratext of Miss Peregrine's Home for Peculiar Children (2011), Riggs explains how his "casual hobby" of collecting vintage snapshots bought in flea markets found its way in his writing. ${ }^{4}$ The photographs, often "haunting" because of a technical flaw, ${ }^{5}$ what Barthes called the punctum, the detail that stings (Barthes, Chambre 49), jolted Riggs' imagination and spurred the narration. ${ }^{6}$ Riggs thus went far beyond novelists' use of a visual "for asserting a sort of fictive referentiality" (Dow Adams XV), ultimately, as he pointed out, the pictures and the story influenced each other in a "strange, organic writing process" (Riggs, Miss Peregrine’s Home 358). Mora remarks that photographs are fragments devoid of meaning and photobiography's first obstacle is "to go from the fragment to the whole;" thanks to the photomontage, "the whole is given a meaning lost by each isolated image" $(185,187)$. The photomontage alone would not lend Riggs' images meaning. It is in the interaction of images and text that meaning is created. Separated from the context that may have

3. Barthes claims that he did not include his mother's photograph in his book because for us, it would have been "nothing more than an indifferent photo" (Chambre II5). Throughout this article, all translations from French are mine.

4. In an online interview, he explains that to fight boredom, he used to look at old pictures when he accompanied his grandmother to tag sales. The snapshots in Miss Peregrine come from his own collection, as well as from eleven more collectors he lists at the end of the book.

As the one on the book cover that makes the little girl seem like she is levitating.

Riggs' project disproves Dow Adams' remark that “[p]hotographs are not naturally very adept at being fictional because of their built-in feeling of accuracy" (3, my italics). Riggs used his snapshots' very lack of feeling of accuracy to turn them into fiction. 
explained them, they were open to a new purpose and interpretation, to a new fictional referentiality. From the peculiarity of the snapshots emerged the home for peculiar children, ruled by its headmistress, Miss Peregrine, and the parallel universe (or loop) of the island of Cairnholm on an ever-repeating September 3, 1940.

The prologue, set in present-day Florida, introduces us to the sixteen-year old narrator, Jacob, and his grandfather Abe, who fled Poland during WWII and found refuge in a children's home in Wales. Through snapshots that Abe takes out of an old cigar box to prove to Jacob that the other children were "peculiar" (14), the prologue introduces three peculiar children: Millard, the invisible boy (16), Olive, the girl lighter than air (17), and the extraordinarily strong Victor (18). Note that peculiar children are most often introduced first visually, without any caption; they are named much later, when Jake actually meets them after uncovering his grandfather's secret—his peculiarity — and as he tries to find the reason for Abe's murder by a "monster." Only three of the ten peculiar children are verbally introduced first: Hugh, "the boy with bees living inside of him" (114; picture 118), Claire who has a "backmouth" (166; picture of her head, front and back 168), and Bronwyn, "The Amazing Strong-Girl of Swansea" (187; picture 188). ${ }^{7}$ The reader-viewer follows Jacob's lead in making the connections between photographs and text (the description or mention of the people on the snapshots) and, once they finally "meet" the peculiars, such as Millard on page 136, the reader-viewer is tempted to look back for the visual. Out of the old snapshots, Riggs unfolds a tale of good vs evil with WWII as its backdrop. Abe and his childhood friends (some from Eastern Europe, like him), safe from monsters in a magnificent house on a Welsh island, may be the Jewish orphans who found shelter from the Nazis in the UK. His tales could also be stories of monsters, ymbryne, ${ }^{8}$ hollowgast and wights ${ }^{9}$ going after the syndrigast, i.e. the peculiar spirits. Unbeknownst to Jake, his grandfather was a peculiar who had the ability to see and sense hollowgast, a gift he passed onto his grandson. Killed at the onset of the novel by a hollow, his last words send Jake on a quest for "the bird" (Miss Peregrine) in the temporal loop of the fateful September 3, 1940 (37), when Miss Peregrine's home for peculiar children was bombed and destroyed. The home can be found on the other side of a tunnel, as illustrated by a picture

In volume two of the trilogy, Hollow City, the peculiar children are also presented visually (in cameos) but before the beginning of the story and their photographs are captioned with their name and peculiarity.

8. Ymbrynes are peculiars that can shape-shift into birds and "manipulate time fields consciously" (I55). They can create temporal loops where peculiars can live indefinitely.

9. As Miss Peregrine tells Jacob, in 1908 an experiment gone bad turned disaffected, renegade peculiars into empty-souled hollows with dangerous ideas pertaining to immortality. These hollowgast attack peculiars for sustenance: "If a hollow gorges itself on enough peculiars, it becomes a wight;" wights have no peculiar ability but can pass for human and act "as scouts and spies and procurers of flesh" for the hollows; "It's a hierarchy of the damned" (258-260). 
(126), one of the very few photographs of the novel that are not character-driven ${ }^{10}$. Indeed, forty-one of the total forty-five snapshots represent people, and therefore characters. ${ }^{11}$ Five of these show Abe: first as an old man (28), then as a young man in the army and with peculiar Emma, his love interest $(227,348)$, with his daughter (231), and on a hunting trip (254). The man's blurred features and his consistently brown hair make it plausible that the pictures represent the same person. The same can be said of Emma, shown as a girl (122) and a young woman (348), and of Horace shown as a child (195) and a teenager (275) - this, however, is inconsistent with the fact that in the loop, that ever-repeating September 3, 1940, peculiars do not age and therefore should always look the same. Similarly, the casual reader-viewer, captivated by the story and under the spell of the vintage pictures and whatever their punctum is, is oblivious to elements that simply do not fit with the time period, such as the people's garb. Riggs establishes intravisual dialogue with photographs of Miss Peregrine as a girl (159) and as an adult (147), using glasses as the identifying element, and with photographs of Victor and of the boys in white clown costumes that are found in different places and time periods, i.e. Abe's cigar box (18, 54) and Miss Peregrine's home $(220,119)$. In each case, the second photograph is used to visually tie the story line: the presence of pictures of the same people in the Welsh home and in Abe's present-day Floridian cigar box confirms the veracity of his outlandish stories. The insertion of another kind of visual in the novel - a police sketch based on Jake's description of Abe's killer (41) - may indicate that the snapshots are merely illustrations for the story. And some are-like the tunnel picture (126). However, some are used as supporting evidence, Jean Arrouye's "probation function" (71). Faced with Jake's doubtful reaction about the existence of peculiars, Abe retorts: "Fine, you don't have to take my word for it [...]. I got pictures!” (14). While most pictures are only visual, some bear an original inscription, which implies that at least some photographs influenced the story. "Remind you of anything? To my bombshell-love, Abe" (227) and "Claire has golden curls" (168) provided the names of two characters and "proved" Claire's peculiarity — the backmouth in her hair. Similarly, the picture of the raven, its wings spread against a gun to show its wingspan, captioned "Caw caw caw" (310), proved the ymbryne Miss Crow's death. Thus, Riggs diverted pictures and inscriptions from their original meaning. More importantly, his photographs spur the reader into action. The non-casual reader-viewer will confront the characters' different pictures and will attempt to match the descriptions. For instance, at the end of the story, the children escape the island on three rowboats but the last

10. Even the bird on page $3 \mathrm{IO}$ is a character, the ymbryne Miss Crow.

11. Interestingly, there is none of Jacob, who visually appears in a cameo at the beginning of Hollow City - and is of course visually represented in the 2013 graphic novel version of Miss Peregrine, where twenty-four of the original forty-five snapshots were retained, one of which was turned into a drawing. The graphic novel obviously changes the photo-textual project and experiments even further since it offers a three-way exchange, i.e. between photographs, drawings, and text. 
photograph shows only one boat (with four people on it). The uncertainty regarding this last picture reflects the diegetic uncertainty, i.e. the peculiars' future in a world of hollowgast and evil. However stimulating, Riggs' project, where the text does not overpower the image, is not as innovative, daring, and complex as Isabelle Monnin's.

\section{Isabelle Monnin: Spurring the reader-viewer into perpetual motion}

Monnin explains in her prologue to Les Gens dans l'enveloppe (2015)—which she calls “user's manual"- how in June 2012 she bought on the Internet pictures of the same family, taken between the 1960s and 2000s. Unlike Riggs she is not a collector. She just liked these pictures, they moved her (80). If family pictures typically record life stages and highlights (Jopeck 88), Monnin's book shows pictures only from the 1970s and early 1980s, the period of her own childhood. Interestingly, the family, the "people in the envelope," originate from the same region as Monnin, who marvels at the coincidence, but quickly inserts doubt in her remark by adding "we'll say" ("Une coïncidence, disons," 180). She also immediately states that she has very few pictures of her own family. Buying these pictures was then not fortuitous; they remedy what may be a deeper lack since, according to psychiatrist Serge Tisseron, family pictures give the feeling of belonging to the same unit, even more so when the family is broken or when the actual proximity is experienced as insufficient (132). The purpose of these photographs goes beyond symbolically putting back together a broken family. Nor is it nosy "gossip reading" (Ansón, 205). Where Riggs created only a novel from vintage snapshots, Monnin's project multiplies the power photographs have of transcending our common, anonymous life into one that deserves to be lived (Soulages 14). Beside a novel, because she is also a journalist, ${ }^{12}$ she wrote an investigative report - in diary form - based on the pictures. She pushed the intermediality so far as to have Alex Beaupain write and record songs based on her texts. To avoid any "interference" (181) between her novel and report, Monnin concluded a pact between the people in the envelope, the idea, and herself (181): she would not investigate the pictures until after she was done writing the novel, and she would not change its plot once she had checked the facts. Her book thus consists of the one-page user's guide, the novel, the photo-album, the investigative report, followed by a genealogical tree with the "People"'s real and fictional names, the CD's user's guide and the transcript of ten of the twelve songs on the CD that is inserted in an envelope - a reproduction of the envelope - glued to the back cover of the book. Let us start with the first major textual component, the "invented story" (259). 
Although she is looking at perfect strangers (related to each other), Monnin, using the girl as her heroine - maybe because they are about the same age — manages to look at the photographs with what Marianne Hirsch called "the familial gaze": "when I look through my family's albums, I enter a network of looks that dictate affiliative feelings, positive or negative feelings of recognition" (53). The girl is actually the first one to attract the reader-viewer's attention on the book cover (Figure 1). Her picture is what I will call a protophotograph, the photograph from which the whole story unfolds. Starting with "Sandrine or Stéphanie or Laurence" (113), Monnin invents a story of abandonment. ${ }^{13}$ The parents, Serge and Michelle, met at a young age, as factory workers. Since only one side of the family is represented and there does not seem to be a mother, Monnin made Serge live a quiet life, surrounded by his mother, Mamie Poulet, his father Raymond, and his aunt Mimi, whereas Michelle is obsessed with leaving (75). In June 1978 she follows an Argentinian co-worker, abandoning her husband and daughter. The novel starts forty-four days later. Laurence is almost eight and waiting for her mother's return. Monnin creates meaning from the phone that appears in the other picture at the top of the book cover, turning the object into Laurence's friend, as well as a witness of and accomplice in her waiting. Monnin thus supports Barthes's emphasis on the importance of objects from which the connoted meaning can emerge (Obvie 16). The viewer cannot help but be puzzled by the phone's center stage position; our gaze is then forced to search for the photograph's meaning in the man sitting to the right, his head bent (Serge), and in the painting of Laurence in the top right corner of this same photograph, which was obviously based on a photograph from the same series as the protophotograph. For Dow Adams, "even a close approximation of a photograph reproduced in painting [...] does not have the same direct connection to reality as an actual photograph" (11). What then can be said of Monnin's outbidding - the photograph of a painting of a photograph? First, it creates meaning for the novel (Michelle finishes painting it on the eve of her departure and asks them to hang it in the dining room, thus leaving a trace of herself behind). Secondly, it creates a collision between the two images that in turn supports Monnin's "invented story." Whereas Laurence is depicted full frontal in the painting, she has a side look in the picture, as if she were looking for her mother outside the frame, outside her "tight life" ("vie étriquée," 328). ${ }^{14}$

13. For Ansón, photographs do not save anything, on the contrary, they underscore all that has been lost (20I).

14. In the rest of the novel, Laurence will travel to Argentina in search of her mother. 


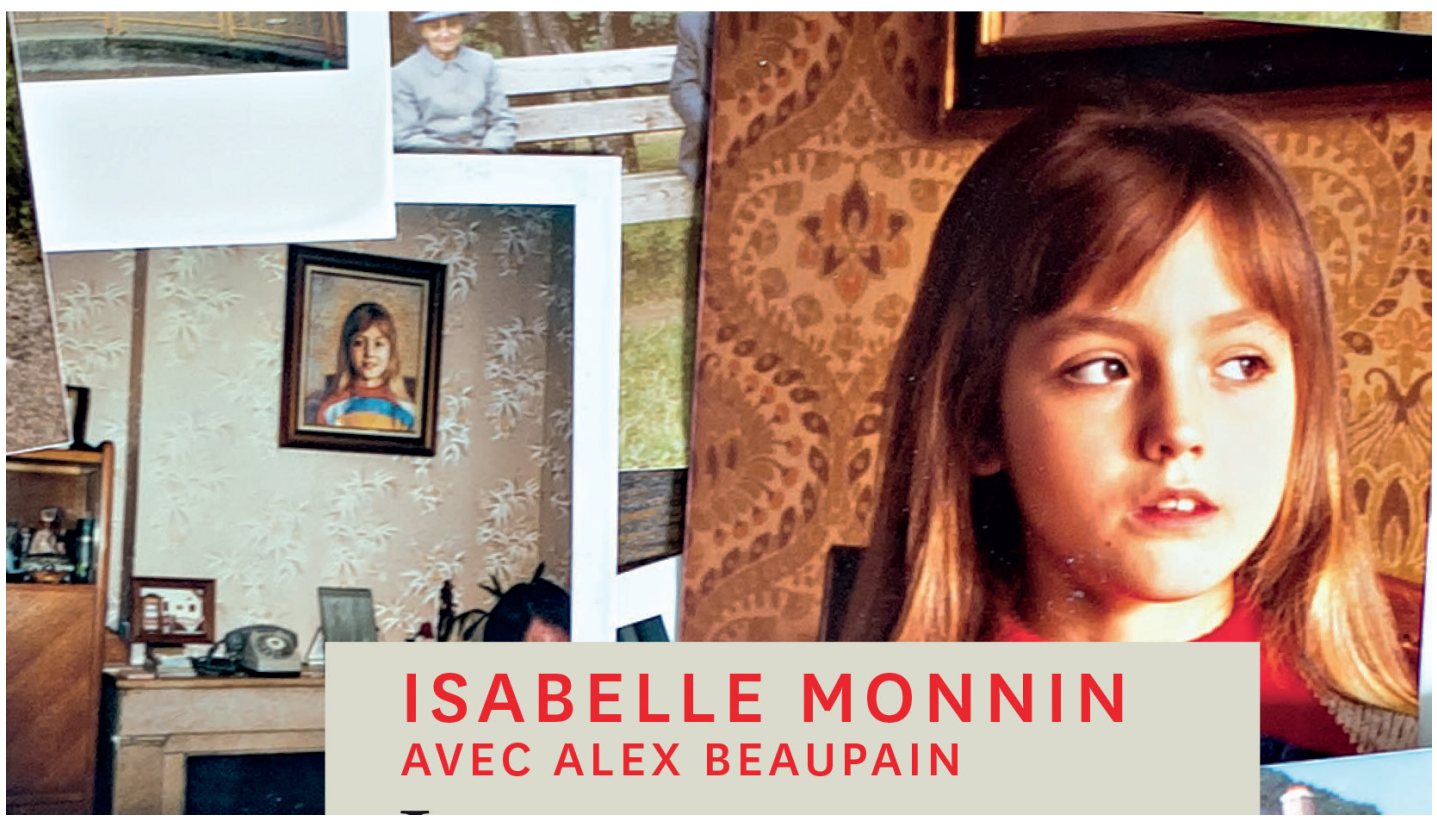

Figure 1: Laurence

What makes Monnin's photo-textual project particularly noteworthy is that the "gathered story" (259) presents uncanny parallelisms with the invented story. The real story is also one of abandonment, but its main character is the girl's father, Michel (aka Serge), who was abandoned four times. ${ }^{15}$ The investigative report's protophotograph is not the picture of Laurence, but that of Clerval's bell tower, which enabled Monnin to identify the village and led her to meeting Michel (Figure 2). ${ }^{16}$

15. An illegitimate, fatherless child, his mother entrusted him to her parents. His wife Suzanne (aka Michelle) left him two years after their daughter was born. His second wife divorced him.

16. Whereas Riggs used the snapshots' punctum to create his fantasy story, Monnin relied on the photograph's studium to identify its geographical context (Barthes, Chambre 48, I48). 


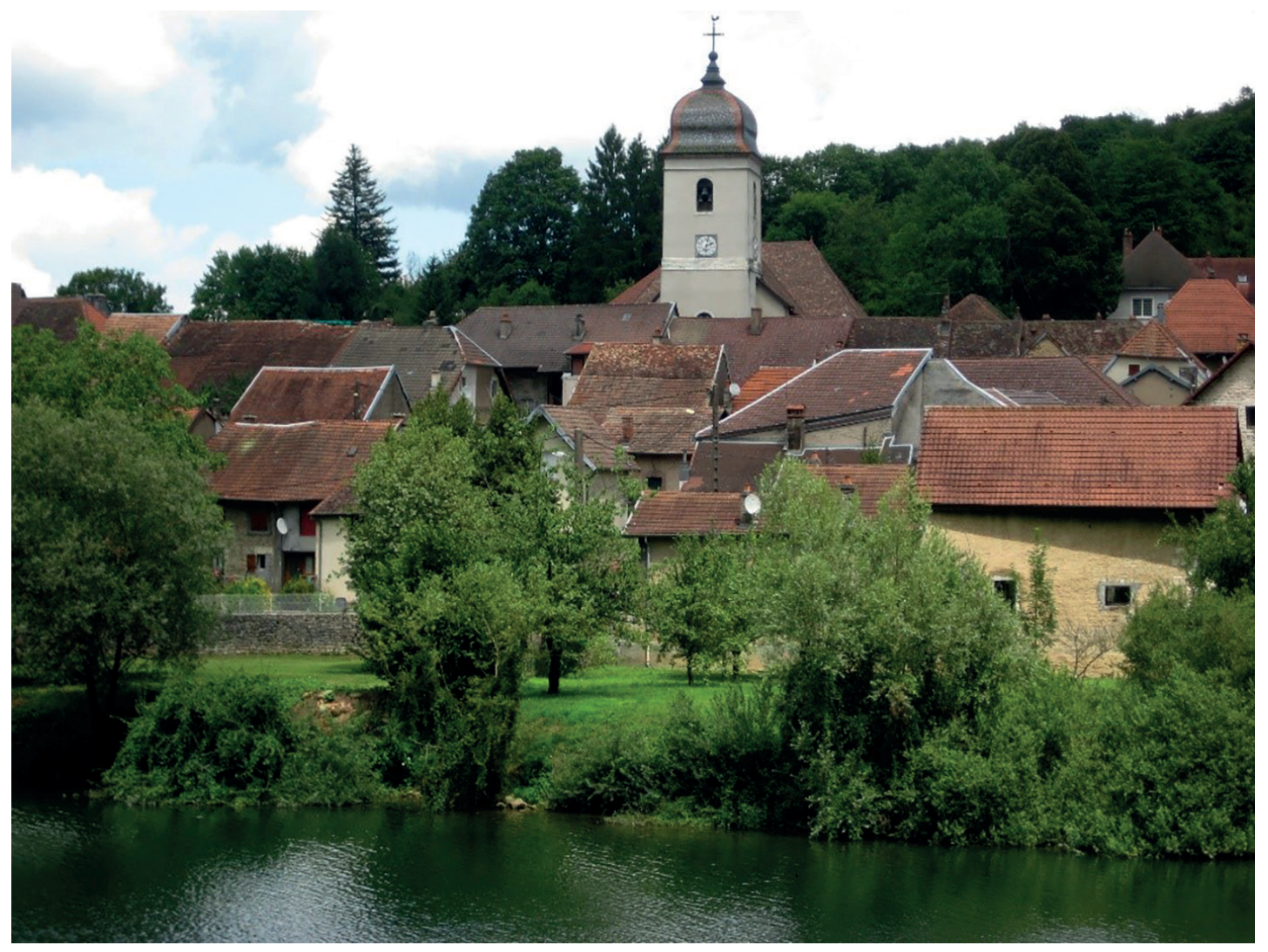

Figure 2: Clerval's bell tower, the "People"'s house in the foreground, along the Doubs river (July 2017)

After being used to invent a story, the family pictures were then used to jog Michel's memory and recover the real story. It turned out that they show four, not three, generations: 1. Laurence (aka Mamie Poulet) and Eugène, 2. Germaine (aka aunt Mimi) and Georges (aka Raymond), 3. Michel (aka Serge) and Suzanne (aka Michelle), and 4. Laurence-who, most strangely, happened to be named Laurence. Just like in the novel, Suzanne did not want to be stuck between the factory and Michel's family. Uncannily, she ordered and gave the painting of Laurence to Michel as a parting gift; in both 
stories, the painting thus bears the same symbolism. In both stories people are lost: Michelle and her lover are victims of the military junta in Argentina and disappear, and the "People" barely left a trace, "They are the true Lost ones" (213). ${ }^{17}$ The intersections are such that Monnin inserted nineteen excerpts from her novel in her investigative report - in italics though, so as not to violate her pact -, which would attest that photographs are more than mere certificates of presence. Monnin challenges Barthes when she writes: "I look at the pictures, I see nothing of what has been" (206). Since family pictures bear "witness to its connectedness" (Sontag 8), the gesture of discarding them (found in both stories) points to the fact that the family was disconnected, scarred by abandonments, which Monnin read in them and included in her novel. By disposing of the family pictures, Michel conveys his unhappiness about his family's actions and maybe even takes revenge. The fate of the painting is in this regard disturbing. If, when given away with the furniture, the photographs could find another purpose, the painting, the symbol of Michel and Suzanne's separation, was discarded, bound for destruction, in what may be interpreted as a vengeful gesture.

However interesting comparing the invented and the real story is, we cannot forget that Monnin's photo-textual project relies heavily on photographs. Four of the twenty-four pictures visually present in the middle section of the book are featured in both the invented (I) and the gathered (G) stories. They are: "the girl in a striped sweater" (I 59 and 107, G 183-4), "the painting" (I 30 and 59, G 185 and 332), "the camping's roasted chicken" (I 42, G 187-8 and 268), and the oysters (I 74, G 310). ${ }^{18}$ The first picture is the only constant, it is also featured on the two paperback editions of the book, which reinforces Laurence's status as heroine and connects the different parts of the project. Tara Collington differentiates between "photographs of space," which examine the relationship between the represented space and its verbalization (here, Clerval), and "space of photographs," which encompasses the choice of the pictures, how they are distributed in the narrative, and the creation of an iconic space alongside a textual space (9). Photographs occupy five spaces in this project. ${ }^{19}$ Within the confines of the actual book, the reader-viewer is forced to roam from picture to text, from front to back cover, from inside front cover sleeve to inside back cover sleeve, in a perpetual movement that will most probably culminate outside of the book, beyond the book limits, in listening to the songs (and maybe following the lyrics in the book) (Figure 3). The reading experience is limitless because the dialogue between the two (and even three) media is. The reader-viewer finds themselves in "a state of mobility, of acrobatic

17. Her investigation proved Monnin wrong since, with the tenuous photographic trace of a white strip on a bell tower, she succeeded in recovering and identifying the "People."

18. Monnin gave a title to the first three.

19. Six, if one also counts the $\mathrm{CD}$, the musical form being a fourth layer after the photographs, the novel, and the investigative report. 
equilibrium, where they try to 'enlighten' the text with the image and vice versa by frequently going back and forth on both sides of the frontier" (Oberhuber 5). Monnin actually nullifies the frontiers, the limits, forcing her reader to a perpetual motion. Danièle Méaux observes that books made of photographs and words produce a dysrhythmia since readers are not used to looking at their components at the same speed, and that such books follow two logics: one (the words) is ordered, whereas the other (the photographs) is more "vagabond" (8). Monnin's book further increases the dysrhythmia by having the reader-viewer roam between five spaces and by adding an auditory component to her photo-textual project. The reading experience of Les Gens dans l'enveloppe is therefore dynamic, the reader-viewer's mobility heightened by the fact that there are two texts (plus songs) that interact with the pictures seen in five places - front and back cover, front and back cover inside sleeves, and middle section.

Whereas the twenty-four pictures in the middle section are presented in an orderly fashion, the twenty-eight identifiable pictures on the front and back covers and inside sleeves are presented pell-mell, some overlapping others, some cropped, some partly hidden by the frames bearing the book title, its summary, and the barcode.

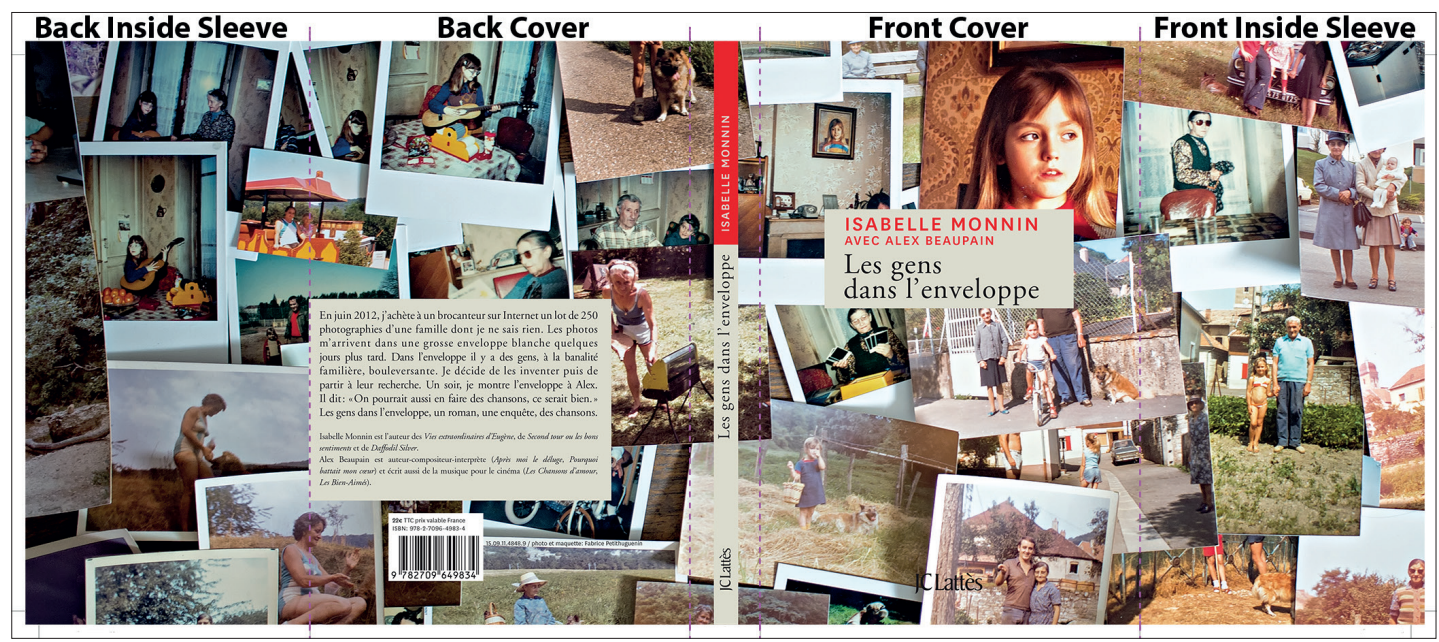

Figure 3: Book covers and inside sleeves 
Neither set is in chronological order; however, the middle section starts with a picture of Laurence (the elder), her husband Eugène, and daughter Germaine ${ }^{20}$ and closes with the picture of Laurence (the younger), thus pointing transmission from one generation to the next as a message. The two sets have nine pictures in common - four of the middle section ones are cropped on the covers and sleeves -, which fosters active reading, the participating reader-viewer building "the work's meaning through their choices of open reading" (Oberhuber 6), by moving freely between and within the different media. If the pictures occupy a definite, albeit multiple, space in the book-those in the middle being like the intersection of a Venn diagram, with the novel and the investigative report as its two circles - the space is multiplied exponentially by the reading experience. The reader's interest and curiosity are first piqued by the "space," or gap, between the novel and the investigative report, which spurs them to take a closer look at the pictures and read in leaps and bounds, forward and backward-by comparison, Riggs' reader-viewer jumps minimally. ${ }^{21}$ Monnin's reader-viewer is not just a participant, nor just an actor in the actualization of her photo-textual project as they are for Riggs', but a creator: a creator of the mental representation of the world depicted in the book, and most importantly a creator of meaning. The reader-viewer must see beyond the invented story and the real story and find on their own where the book's real meaning lies, which is not the case with Riggs, where the reader is not as personally involved in the story, but a mere witness, an accompanist at best.

One should not judge a book by its cover and, unlike Barthes argued-"a pipe is always a pipe" (Chambre 17) -, by nature there is not always something tautological in a photograph. Similarly, Laurence is not Laurence, as can be inferred from the book Monnin published after Les Gens, Mistral perdu ou les événements (2017). Mistral perdu, a narrative about "les filles," two twin-like sisters growing up in the 1970s in the Doubs region, is clearly a memoir. In her ekphrasis of the "girl in a striped sweater" picture, Monnin undoubtedly invites us to consider Laurence as a double of herself (and of her twin-like sister Aude): they listened to the same songs and dreamed about the same celebrities, they "lived the same kind of childhood" (184). Laurence's portrait is in fact an "allo-portrait," "the portrait of the other, defined as the other within" (Hirsch 85). Laurence stands for Aude, who died in 2000 at age 26, the sister Monnin carries within her. ${ }^{22}$ It is because it is an allo-portrait that Monnin is able to look at Laurence's pictures with a "familial gaze," except that here the familial gaze is not about "recognizing" an ancestor but about searching for people who have disappeared. Monnin admits in Les Gens that "looking for your [Laurence's] family is like finding my own" (325). Laurence and Aude

20. Judging by Germaine's appearance, it is the oldest picture of the set.

21. There is also only one picture on the book cover and none on the back cover.

22. Christophe Honoré's musical film Chansons d'amour, with songs written by Alex Beaupain, Aude's companion and the composer of the songs in Les Gens, is loosely based on her death. 
were born only one year apart (1974 and 1975), they did have the same kind of childhood. They both come from the Doubs region, Clerval lies only about sixty kilometers away from Monnin's childhood home. Looking at and for Laurence's family, Monnin was in fact looking for her own "disparus," her lost ones: her sister Aude ${ }^{23}$ and her deceased newborn Eugène. ${ }^{24}$ By using these pictures, Monnin has "imaged the inimageable" (Buignet 487). Using the rift caused by pictures in the middle section and the rift in the photographed and painted portraits of Laurence, the "scission" within them and between them, ${ }^{25}$ Monnin has made space for Aude and baby Eugène to emerge. This photo-textual project thus enables her to prove that each life bears witness to all lives (282), that behind each person "us, us all, us total" (207) can be seen. Monnin's photo-textual project is transpersonal in nature. In fact, I will argue that with Les Gens dans l'enveloppe, Monnin practices psychogenealogy, and even transpsychogenealogy. One can indeed read it as a photo-textual version of a "genosociogram," i.e. a genealogical tree augmented by important family ties and life events (Ancelin-Schützenberger, Psychogénéalogie 11). ${ }^{26}$ Psychologist Anne Ancelin-Schützenberger adds that what is important in a genosociogram are "the spaces, the family's memory lapses that tell a lot [...] about what has been 'stricken from the family's memory" (Aïe 89). It is very tempting to see in these "blancs" (lapses) Buignet's "béances" (rifts), where one finds Aude and Eugène since "Little Eugène doesn't see the light of day, old Eugène is blind" (229). Thus, Monnin's genosociogram proves to be a transgenosociogram. As such, it calls upon the reader-viewer to find their own people and lost ones. The dedication Monnin wrote in my copy of the book attests to that ${ }^{27}$ : by entrusting me with her people, she handed me the baton, which I hand in turn to this reader.

By repurposing existing photographs of and by others, Riggs and Monnin explored the possibilities photographs offer and pushed back the limits of photo-textuality. Out of vintage snapshots, Riggs created a riveting fiction. By not captioning his photographs and creating in the novel a spatial and temporal space between them and the characters they feature, he spurred his reader-viewer into action. Monnin's photo-textual project goes even further since by offering a novel and an investigative report of the pictures, which are placed inside the book but also in its liminal—sometimes even

23. "I'm looking for what's left of the People in the envelop so that my sister doesn't disappear" (347).

24. "Eugène, the blind man. [older Laurence's husband]/ Eugène, my ephemeral child's name, a breath of life and then he went" (228). Her first novel, Les Vies extraordinaires d'Eugène, recounted the baby's death and the ensuing mourning. Mistral perdu is about these two losses.

25. Buignet claims that images are haunted by scissions that open up the imagination to what has not occurred (5OI).

26. Such relationships and highlights are in both the novel and the investigative report and, as mentioned earlier, an actual genealogical tree (with the real and the invented names) is included towards the end of the book.

27. "For Michèle. I invented them, looked for them, sang them, I now entrust you with My People in the Envelope." 
hidden-spaces, she amplifies the inherent polysemous nature of photographs and makes her book a performative space, where the reader-viewer creates meaning both about the photo-text and about themselves. In his snapshots, Riggs found fame, ${ }^{28}$ in the "People's"' pictures, Monnin found her story and herself and, through the transpsychogenealogical nature of her project, she invites us to search for ourselves.

\section{Works Cited}

ANCELIN-SCHÜTZENBERGER, Anne. Aïe, mes aïeux. Paris: Desclée de Brouwer, 1993.

—. Psychogénéalogie. Guérir les blessures familiales et se retrouver soi. 2007. Paris: Payot, 2012.

ANSÓN, Antonio. "Photos de famille. Littérature et photographie.” Les Lettres romanes 63.3-4 (2009): 201-09.

ARROUYE, Jean. "Un nouvel art de dire et de montrer." Livres de photographies et de mots. Ed. Danièle Méaux. Caen: lettres modernes minard, 2009. 53-73.

BACHOLLE, Michèle. "ph-auto bio graphie: Écrire la vie par des photos (Annie Ernaux)." Women in French Studies 21.1 (2013): 79-93.

—. Un appelé dans la guerre d'Algérie. Témoignage photo-textuel. Paris: L'Harmattan, 2016.

BARTHES, Roland. La Chambre claire. Note sur la photographie. Paris: Gallimard/Seuil, 1980.

—. L'Obvie et l'obtus. Paris: Seuil, 1982.

BLATT, Ari J. "The Interphototextual Dimension of Annie Ernaux and Marc Marie's L'Usage de la photo." Word and Image 25.1 (Jan-March 2009): 46-55.

BUIGNET, Christine. "Tropismes photographiques. Indicible et Inimageable." Littérature et Photographie. Ed. Jean-Pierre Montier et al. Rennes: Presses Universitaires de Rennes, 2008. 497-514.

COLlington, Tara. "La Photographie de l'espace, l'espace de la photographie: Le Disparu de Salonique." Arborescences: revue d'études françaises 3 (2013). <http://id.erudit.org/iderudit/1017371ar>

DOW ADAMS, Timothy. Light Writing and Life Writing: Photography in Autobiography. Chapel Hill: The University of North Carolina Press, 2000.

28. Miss Peregrine's Home for Peculiar Children was turned into a graphic novel in 20I3, has three sequels - Hollow City (also turned into a graphic novel in 20I6), Library of Souls, and A Map of Days - and one spin-off, Tales of the Peculiar. It was adapted to the cinema by Tim Burton in 2016. 
GARNIER, Marie-Dominique. Jardins d'hiver. Littérature et photographie. Paris: Rue d'Ulm, 1997.

GROJNOWSKI, Daniel. Usages de la photographie. Paris: José Corti, 2011.

HIRSCH, Marianne. Family Frames: Photography, Narrative, and Postmemory. Cambridge: Harvard University Press, 1997.

HONORÉ, Christophe (ed.). Chansons d'amour. Screenplay by Christophe Honoré. Alma Films, 2007.

JOPECK, Sylvie. La Photographie et l'(auto)biographie. Paris: La bibliothèque Gallimard, 2004.

MÉAUX, Danièle. “Le Livre de photographies et de mots. Un espace de brouillage et d'interférences.” Livres de photographies et de mots. Ed. Danièle Méaux. Caen: lettres modernes minard, 2009. 7-18.

MONNIN, Isabelle. Les Gens dans l'enveloppe. Paris: JC Lattès, 2015.

—. Les Vies extraordinaires d'Eugène. Paris: JC Lattès, 2010.

—. Mistral perdu ou les événements. Paris: JC Lattès, 2017.

MORA, Gilles. "La Photobiographie. Une forme d'autobiographie ?” RITM 20 (1999): 183-189.

OBERHUBER, Andrea. "Présentation: Texte/image, une question de coöncidence." Dalhousie French Studies 89 (2009): 3-9.

RIGGS, Ransom. Miss Peregrine's Home for Peculiar Children. New York: Quirk Books, 2011.

- Miss Peregrine's Home for Peculiar Children: The Graphic Novel. Illust. Cassandra Jean. New York: Yen Press, 2013.

—. Hollow City. New York: Quirk Books, 2014.

—. Library of Souls. New York: Quirk Books, 2015.

—. Tales of the Peculiar. New York: Quirk Books, 2016.

—. Hollow City: The Graphic Novel. Illust. Cassandra Jean. New York: Yen Press, 2016.

—. A Map of Days. New York: Dutton Books, 2018.

SONTAG, Susan. On Photography. New York: Farrar, Straus and Giroux, 1973.

SOULAGES, François. Esthétique de la photographie. La Perte et le reste. Paris: Nathan, 1998.

TISSERON, Serge. Le Mystère de la chambre claire. Photographie et inconscient. Paris: Les Belles Lettres, 1996. 
Abstract: In Miss Peregrine's Home for Peculiar Children (2011) and Les Gens dans l'enveloppe (2015) respectively, American writer Ransom Riggs and French journalist and writer Isabelle Monnin illustrate Barthes's statement that photographs only attest to what has been. Both became "haunted" enough by pictures of others that they felt the need to give them a context. This article examines how both writers - albeit differently - integrated photographs in a dynamic photo-textual project that requires the reader-spectator's active participation in the creation of meaning. In addition to being more complex, we will see how Monnin's project's transpersonal nature calls for a psychogenealogical reading.

Résumé : Dans Miss Peregrine's Home for Peculiar Children (2011) et Les Gens dans l'enveloppe (2015), l'écrivain américain Ransom Riggs et la journaliste et écrivaine française Isabelle Monnin illustrent la déclaration de Barthes selon laquelle les photographies ne font qu'attester de ce qui a été. Tous deux furent tellement habités par des photos d'autrui qu'ils ressentirent le besoin de leur donner un contexte. Cet article examine comment les deux écrivains - quoique différemment - ont intégré des photos dans un projet photo-textuel dynamique qui requiert la participation active du lecteur dans la création du sens. En sus d'être plus complexe, nous verrons que la nature transpersonnelle du projet de Monnin invite à une lecture psychogénéalogique. 